\title{
Rearing and handling injuries in broiler chickens and risk factors for wing injuries during loading
}

\author{
Michael S. Cockram, Ketan Jung Dulal, Henrik Stryhn, and Crawford W. Revie
}

\begin{abstract}
Some injuries to broilers occur during rearing, but most injuries occur during handling before slaughter. Records provided by a processing plant for loads transported over a 19 mo period during 2009 and 2010 were examined. The median percentage of wing injuries per load was 5.7\%, whereas injuries to the legs, breast, or shoulders were all less than $1 \%$ per load. Risk factors for wing injuries were examined by considering the data from each load by handling event (i.e., loads originating from the same producer on the same date). A multilevel model with three levels, producer $(n=86)$, handling event $(n=1694)$, and load $(n=4219)$, was fitted. The final model included weight, sex, season, catching team, time of day at which loading began, speed of loading, and an interaction between speed of loading and time of day. Factors that reduced the risk of wing injuries were loading lighter birds, loads containing only cockerels, and loading in the fall. The predicted percentage of wing injuries was relatively constant for slower loading speeds, but it was increased significantly when faster loading speeds were adopted during daytime (0700-1700). Identification of these risk factors can be used to adjust loading practices.
\end{abstract}

Key words: broilers, bruising, handling, injuries, loading, welfare.

Résumé : Certaines blessures aux poulets à griller surviennent lors de l'élevage, mais la plupart des blessures se font pendant la manutention avant abattage. Les registres fournis par une usine de transformation pour les chargements transportés pendant une période de 19 mo de 2009 et 2010 ont été examinés. La moyenne des pourcentages de blessures aux ailes par chargement était de 5,7 \% tandis que les moyennes des blessures aux jambes, poitrines, ou épaules étaient tous moins de $1 \%$ par chargement. Les facteurs de risques pour les blessures aux ailes ont été étudiés en considérant les données de chaque chargement par événement de manutention (c.-à-d., les chargements provenant du même producteur à la même date). Un modèle multi-niveau à trois niveaux : producteur $(n=86)$, événement de manutention $(n=1694)$ et chargement $(n=4219)$ a été élaboré. Le modèle final incluait : poids, sexe, saison, équipe de capture, temps de la journée auquel le chargement a commencé, vitesse de chargement, et une interaction entre la vitesse de chargement et le temps de la journée. Les facteurs qui réduisent les risques de blessures aux ailes étaient le chargement de poulets plus légers, les chargements de coquelets seulement, et les chargements à l'automne. Le pourcentage prévu de blessures aux ailes était relativement constant pour les vitesses moins rapides de chargement, mais était significativement plus élevé lorsque les chargements plus rapides ont été adoptés dans le jour (0700-1700). L'identification de ces facteurs de risque peut être utilisée pour modifier les pratiques de chargement. [Traduit par la Rédaction]

Mots-clés : poulets à griller, contusions, manutention, blessures, chargement, bien-être.

\section{Introduction}

The transport of broilers to slaughter is a multi-stage process and many factors can affect the risk of injury (Cockram and Dulal 2018). In Canada, broilers are caught and handled manually and if this is undertaken carefully, injuries need not occur and most birds are not injured (Kettlewell and Turner 1985). However, manual catching and handling of broilers have the potential to cause trauma that can result in injuries (Jespersen 1982; Griffiths and Nairn 1984). These injuries are likely to cause pain and discomfort to the birds (Gentle 1992) and represent an economic loss due to condemnations,

Received 28 November 2019. Accepted 27 January 2020.

M.S. Cockram, K.J. Dulal, H. Stryhn, and C.W. Revie. Department of Health Management, Atlantic Veterinary College, University of Prince Edward Island, 550 University Avenue, Charlottetown, PE C1A 4P3, Canada.

Corresponding author: Michael S. Cockram (email: mcockram@upei.ca).

Copyright remains with the author(s) or their institution(s). This work is licensed under a Creative Commons Attribution 4.0 International License (CC BY 4.0), which permits unrestricted use, distribution, and reproduction in any medium, provided the original author(s) and source are credited. 
trimming of parts of the carcase (Hamdy et al. 1961b), and sometimes mortality (Bayliss and Hinton 1990).

In Canada, teams of catchers provided by the processor are used to load the broilers from the barn. They catch the birds by grasping the legs of the birds until several birds are held in each hand. The birds are then picked up from the floor, carried inverted, and put into a receptacle consisting of a crate or a module placed either inside or outside of the barn. In some situations, the birds are transferred between handlers. Catching, lifting, holding, and carrying a broiler inverted by its legs can cause wing flapping and struggling (Newberry and Blair 1993), and places an unnatural strain on the joints, especially the hip joint. When birds are placed into a crate, they can flap and injure their wings (Knowles and Broom 1990). Bruising, dislocation, haemorrhage, and sometimes, death can occur (Wilson and Brunson 1968; Mitchell and De Boom 1986; Gregory 1994). The manner in which the birds are carried and placed in a receptacle affects the risk of injury (Gerrits and de Koning 1982). The percentage of birds with bruised wings or breasts can vary between catching teams (Taylor and Helbacka 1968; Langkabel et al. 2015).

Bruising is a superficial injury that occurs after trauma (Hamdy et al. 1961b). However, it can be difficult to differentiate bruising following trauma from haemorrhage that can occur from other potential causes between catching and processing (Kranen et al. 2000). Although there is considerable variation, recent bruising appears red; between 12 and $24 \mathrm{~h}$ after trauma, the bruise is often dark red to purple (Hamdy et al. 1961a; Kranen et al. 2000; Northcutt et al. 2000). Bruising that occurs during rearing can potentially be identified by a green colouration that occurs $24-48 \mathrm{~h}$ after trauma (Hamdy et al. 1961a).

A number of factors have been identified as affecting the risk of injury: type of handling system, loading and transport in the summer compared with the fall or spring, loading in daytime compared with night time, and at an ambient temperature of $\leq 5{ }^{\circ} \mathrm{C}$ compared with warmer temperature (Nijdam et al. 2004). This study aimed to describe the types of injuries recorded at a processing plant, their prevalence, and to identify risk factors for these injuries. Identification of risk factors for injuries during handling before broiler chickens are transported would identify management practices that could reduce injuries and lead to subsequent implementation of strategies to improve the welfare of broiler chickens.

\section{Material and Methods}

\section{Handling and transport procedures}

Injuries (i.e., the percentage of birds within a trailer load of birds that were recorded by the processing plant as injured) and potential risk factors for injuries were studied using records made by a processing plant in Canada between January 2009 and July 2010. A total of
4494 loads of broiler chickens originating from 86 different producers (range 1-246 loads per producer) were included in the study. There were 3066 mixed-sex loads, 601 loads of cockerels, and 827 loads of pullets. The birds had been caught and loaded using a manual catching system that involved carrying the birds and loading them into loose plastic crates $(0.9 \mathrm{~m}$ long $\times 0.6 \mathrm{~m}$ wide approximately). The number of birds per crate depended on the environmental conditions, as well as the sex and weight of the birds, and essentially varied between 10 and 15 (recommended crate stocking density ranged between 30 and $56 \mathrm{~kg} \mathrm{~m}^{-2}$ ). The number of crates on each trailer varied from about 600 to 800 ; the median number of crates per trailer loaded with birds was about 700 and about half of the loads had no empty crates. After loading, the broilers were transported for between 0.1 and $16 \mathrm{~h}$ to the processing plant in either two- or three-axle trailers. One type of trailer used tarpaulins to cover the sides and top of the trailer, whereas the other type used sliding panels to cover the sides and top of the trailer. After a holding period at the processing plant, the birds were unloaded, any dead-on-arrival birds were removed, and the remaining birds were shackled, electrically stunned, and exsanguinated. After feather removal, a sample of carcases from each load was observed by processing plant staff. Any bruising or hip dislocation observed in these birds was recorded and classified, based on experience, colour of bruising, location, and characteristics, as having occurred during rearing, prior to the start of catching (old injury); during catching, handling, and transport (recent injury); or at the processing plant during unloading, shackling, stunning, or processing.

\section{Processing plant records and data handling}

The processing plant provided data in the form of digital spreadsheets and scanned forms containing handwritten records. Each load of broilers transported from a producer to the processing plant was uniquely identified using the date, producer, trailer number, and number of birds loaded. These data were collated and organised by date and load. As multiple loads were often collected from the same producer in one handling event, each load was not considered to be an independent event. To account for potential clustering, the load data were nested within different "handling events". A "handling event" consisted of loads collected from the same producer and slaughtered within a $24 \mathrm{~h}$ period. There were 4494 loads, nested within 1694 events from 86 producers. Seasons were defined based on the spring and fall equinox and summer and winter solstice dates for 2009-2010. The time of day when loading began was grouped into three categories: 0000-0700, 0701-1700, and 1701-2359. For each load, the percentage of daylight present during loading was calculated using the times of sunset and sunrise for the days on which handling 
Table 1. Descriptive statistics for injuries (bruising and hip dislocation) based on all 4494 loads reported from 1694 loading events.

\begin{tabular}{|c|c|c|c|c|c|c|}
\hline \multirow{2}{*}{$\begin{array}{l}\text { Presumed stage and } \\
\text { location/type of injury }\end{array}$} & \multirow{2}{*}{$\begin{array}{l}\% \text { of loads with at least one bird } \\
\text { with each type of injury }\end{array}$} & \multicolumn{5}{|c|}{$\%$ of birds in load with each type of injury } \\
\hline & & Minimum & $Q_{1}$ & Median & $Q_{3}$ & Maximum \\
\hline \multicolumn{7}{|c|}{ Rearing barn (“old” injuries) } \\
\hline Wing & 41.1 & 0.0 & 0.0 & 0.0 & 0.3 & 11.7 \\
\hline Breast & 9.1 & 0.0 & 0.0 & 0.0 & 0.0 & 6.3 \\
\hline \multicolumn{7}{|c|}{ Handling and transport ("recent" injuries) } \\
\hline Wing & 99.6 & 0.0 & 4.0 & 5.7 & 7.7 & 20.7 \\
\hline Leg & 95.1 & 0.0 & 0.3 & 0.7 & 1.0 & 6.3 \\
\hline Breast & 66.3 & 0.0 & 0.0 & 0.3 & 0.3 & 5.7 \\
\hline Dislocated hip & 20.7 & 0.0 & 0.0 & 0.0 & 0.0 & 4.0 \\
\hline Shoulder & 0.5 & 0.0 & 0.0 & 0.0 & 0.0 & 0.7 \\
\hline
\end{tabular}

events occurred (Thorsen 2017). The speed of loading was categorised as $<5000$ or $\geq 5000$ birds $h^{-1}$.

\section{Statistical analysis}

Descriptive statistics were generated and these indicated that wing injuries attributed to handling were the only type of injury that occurred frequently enough to justify a full analysis of associated risk factors. An examination of the distribution of the percentage of wing injuries per load indicated that there were a substantial proportion of loads for which a very low percentage of wing injuries was reported. During preliminary model fitting, these loads had a major influence on the results. Therefore, a model was built using data from loads where the percentage of wing injuries per load attributed to handling was $\geq 2 \%$ ( $n=4219$ loads). This excluded 275 loads where the percentage of wing injuries was $<2 \%$, as well as 16 loads for which the percentage of wing injuries was not reported. A square root transformation of the percentage of wing injuries per load attributed to handling was undertaken to meet the modelling assumptions. A multilevel linear mixed model, using handling event and producer as random effects, was fitted to the data. For categorical variables, "dummy" variables were created according to whether the variable was in that particular category, and these were compared with a reference category. First, each predictor was modelled with the outcome variable to ascertain whether there was an unconditional association. Any predictors that did not show an unconditional association at a liberal significance level $(P<0.2)$ were not considered for multivariable modelling.

Thereafter, a manual backward elimination process was used to construct the final model, starting with a maximum model that included all potential predictors identified by their unconditional associations. A Wald test was used to remove predictors that did not show any significant association. Collinearity between different predictors was also assessed during the model building process. Testing for interactions occurred after the model was built and the following interactions were tested: between season and percentage of daylight during loading, age and weight, sex and weight, time of day at which loading began and season, and between speed of loading and time of day. Linearity between the continuous predictors and the outcome variable was assessed using scatterplots. If the continuous predictor did not have a linear relationship with the outcome variable, then either a polynomial form of the predictor was included in the model or the variable was categorized. Akaike's information criteria (AIC) was used to compare different models. Homoscedasticity and normality of residuals in the final models were checked graphically for both random effects and error terms.

Out of 4219 loads that had a percentage of wing injuries per load attributed to handling $\geq 2 \%, 593$ loads had either missing values for the speed of loading or had insufficient information on the start and end times of loading to be able to correctly allocate the time of day or proportion of daylight during loading. These observations were included in the analysis as a separate group identified by the predictor: missing. The random effects of producer and event were also included in the model. The effect of each factor was reported as a coefficient. Pairwise multiple comparisons were evaluated using Bonferroni corrections for the significant main effects and the interactions. Relationships between the backtransformed predicted percentage of wing injuries and different values of variables that were included in the final model are shown graphically. All statistical analyses were performed in Stata, version 13 (StataCorp LLC., College Station, TX, USA).

\section{Results}

\section{Rearing barn injuries}

Some loads contained birds with old injuries (i.e., injuries categorised as having occurred before the start of catching), but the majority of loads had no birds with old injuries (Table 1). The median percentage of loads per producer with no old wing injuries was $57 \%\left(Q_{1} 50\right.$ and $Q_{3} 64$ ). Five percent of producers had $>5 \%$ of their loads with $>1 \%$ of the birds with old wing injuries. 
Fig. 1. Distribution of wing injuries by load.

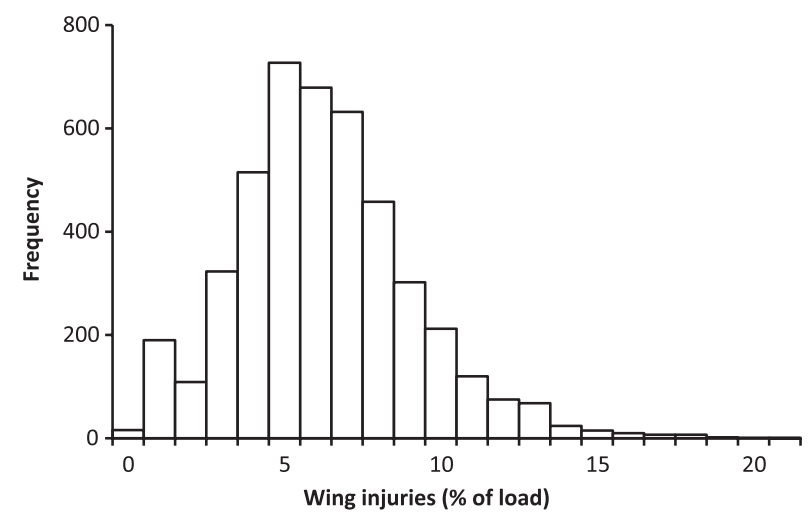

The median percentage of loads per producer with no old breast injuries was $92 \%\left(Q_{1} 87\right.$ and $\left.Q_{3} 96\right)$. About $1 \%$ of producers had $>5 \%$ of their loads with $>1 \%$ of the birds with old breast injuries.

\section{Recent catching injuries}

In the vast majority of loads, the percentage of birds with recent wing injuries was more frequent than all other types of recent injuries combined (Table 1). Figure 1 shows the distribution of wing injuries per load. The median percentages of loads with leg bruising and with breast bruising were $0.7 \%$ and $0.3 \%$, respectively. Most loads did not have any birds with shoulder bruising, with only slightly more reporting a dislocated hip. The median percentage of recent leg (0.7-1.0) and breast (0.3) injuries per load did not appear to vary greatly among catching teams. There was no clear linear relationship between bird weight and the percentage of birds per load with a hip dislocation.

\section{Factors affecting risk of wing injuries}

A range of descriptive statistics that may act as potential risk factors for wing injuries are shown in Table 2. The vast majority of loads (88\%) involved loading 10 birds per crate, with less than $1 \%$ of loads involving the maximum of 15 birds per crate. Of those loads for which loading time data were available $(n=3848)$, only $23 \%$ were loaded entirely in daylight, whereas $69 \%$ of loads were loaded during a period when less than $50 \%$ of the period was daylight.

Unconditional associations between different variables and the square-root-transformed outcome (with their mean or frequency) are shown in Table 3. The variables associated with the percentage of wing injuries in a univariate analysis were bird weight, age and sex, season, catching team, loading duration, percentage of daylight during loading, and number of birds per crate.

The final model included seven effects: weight, sex, season, catching team, time of day during which catching took place, speed of loading, and an interaction between speed of loading and time of day during loading
Table 2. Descriptive statistics on age and weight of the birds and loading variables.

\begin{tabular}{lllll}
\hline & $\begin{array}{l}\text { No. of } \\
\text { loads }\end{array}$ & $Q_{1}$ & Median & $Q_{3}$ \\
\hline Birds & & & & \\
$\begin{array}{l}\text { Age (d) } \\
\text { Weight (kg) }\end{array}$ & 4494 & 37 & 38 & 40 \\
$\begin{array}{l}\text { Loading } \\
\text { Number of birds }\end{array}$ & 4494 & 2.20 & 2.27 & 2.35 \\
$\quad$ per load & & 6120 & 6800 & 7608 \\
$\begin{array}{l}\text { Loading duration (h) } \\
\text { Speed of loading } \\
\quad \text { (birds h }{ }^{-1} \text { ) }\end{array}$ & 3848 & 1.42 & 1.67 & 1.92 \\
\hline
\end{tabular}

(Table 4). Bird age and weight were correlated $(r=0.51)$. Bird weight was used in the model because it provided more variation than bird age. Percentage of daylight during loading was also significant in the model, but time of day categories were used due to lower AIC values.

The final model (Table 4) indicated that increased bird weight increased the risk of wing injuries $(P<0.001)$ (Fig. 2). Loads that contained only cockerels had a lower percentage of wing injuries than loads with mixed-sex and only pullets $(P<0.001)$ (Fig. 3$)$. The comparison between mixed loads and pullets was not significant. Loading in the fall was associated with a significantly lower risk of wing injuries than loading in the winter, spring, and summer $(P<0.001)$ (Fig. 4). Comparisons between summer and spring, winter and spring, and winter and summer were not significant. Catching team I had a lower estimated percentage of wing injuries compared with a number of the other catching teams (Fig. 5).

The largest unexplained variation was among loads, a modest amount of unexplained variation existed among handling events, whereas different producers did not account for any substantial amount of variation (Table 4). There was a significant interaction between the time of day at which loading took place and the speed of loading (Table 4). During daytime (0701-1700), the percentage of wing injuries was significantly greater at faster loading speeds $\left(\geq 5000\right.$ birds $\left.h^{-1}\right)$. At slower loading speeds $\left(<5000\right.$ birds $\left.h^{-1}\right)$, the percentage of wing injuries was more uniform throughout the day, with some evidence of a lower percentage of injuries when loading took place between 1700 and midnight compared with other times of the day (Fig. 6).

\section{Discussion}

As this study examined injuries in broilers caught, loaded into crates, and transported to one processing plant, the prevalence of different types of injuries and some risk factors will be specific to the handling system, region, and the processing plant. The study was a retrospective observational study of data collected by a 
Table 3. Exploring variables for inclusion in the full model using a univariate modelling of association with the square root transformed percentage of wing injuries per load.

\begin{tabular}{|c|c|c|c|c|}
\hline Variable & No. of loads & Frequency (\%) or mean (SD) & Coeff. & $P$ \\
\hline \multicolumn{5}{|l|}{ Birds } \\
\hline Age (d) & 4219 & $38.6(1.92)$ & 0.02 & 0.001 \\
\hline Weight (kg) & 4219 & $2.26(0.14)$ & 0.32 & 0.001 \\
\hline Sex & - & - & - & $<0.001$ \\
\hline Cockerels & 546 & $12.9 \%$ & Reference & - \\
\hline Mixed & 2887 & $68.4 \%$ & 0.20 & - \\
\hline Pullets & 786 & $18.6 \%$ & 0.15 & - \\
\hline \multicolumn{5}{|l|}{ Loading } \\
\hline Catching team & - & - & - & $<0.001$ \\
\hline I & 525 & $12.4 \%$ & Reference & - \\
\hline A & 918 & $21.8 \%$ & 0.51 & - \\
\hline B & 407 & $9.7 \%$ & 0.38 & - \\
\hline $\mathrm{C}$ & 97 & $2.3 \%$ & 0.85 & - \\
\hline $\mathrm{D}$ & 494 & $11.7 \%$ & 0.37 & - \\
\hline $\mathrm{E}$ & 370 & $8.8 \%$ & 0.43 & - \\
\hline $\mathrm{F}$ & 410 & $9.7 \%$ & 0.53 & - \\
\hline G & 30 & $0.7 \%$ & 0.45 & - \\
\hline $\mathrm{H}$ & 107 & $2.5 \%$ & 0.44 & - \\
\hline $\mathrm{J}$ & 861 & $20.4 \%$ & 0.55 & - \\
\hline Season & - & - & - & $<0.001$ \\
\hline Fall & 558 & $13.2 \%$ & Reference & - \\
\hline Spring & 1398 & $33.1 \%$ & 0.18 & - \\
\hline Summer & 1021 & $24.2 \%$ & 0.19 & - \\
\hline Winter & 1242 & $29.4 \%$ & 0.11 & - \\
\hline Time of day & - & - & - & $<0.001$ \\
\hline 0000-0700 (Morning) & 953 & $22.6 \%$ & Reference & - \\
\hline 0701-1700 (Daytime) & 695 & $16.5 \%$ & 0.08 & - \\
\hline 1701-2359 (Evening) & 1995 & $47.3 \%$ & -0.13 & - \\
\hline No time of day recorded & 576 & $13.7 \%$ & -0.14 & - \\
\hline$\%$ of loading during daylight & 3629 & $32.3(43.2)$ & 0.002 & $<0.001$ \\
\hline Loading duration $(\mathrm{h})$ & 3629 & $1.70(0.46)$ & -0.05 & 0.046 \\
\hline Speed of loading (no. of birds $h^{-1}$ ) & - & - & - & 0.040 \\
\hline$<5000$ & 2985 & $70.8 \%$ & Reference & - \\
\hline$\geq 5000$ & 641 & $15.2 \%$ & 0.02 & - \\
\hline No speed of loading recorded & 593 & $14.1 \%$ & -0.08 & - \\
\hline Crate stocking density (no. of birds per crate) & - & - & - & 0.006 \\
\hline 10 & 3733 & $88.5 \%$ & Reference & - \\
\hline$>10$ & 486 & $11.5 \%$ & -0.09 & - \\
\hline
\end{tabular}

Note: SD, standard deviation.

processing plant during 2009 and 2010, and some procedures may have changed since this time. As the study used records collected by the processing plant during commercial operations, the reliability of the data collected cannot be verified. We were not able to verify the method of sampling, observation, categorisation, and recording of injuries. For example, categorisation of the stage in which the injury most likely occurred was dependent on the experience and judgement of the personnel at the processing plant.

A major issue when examining postmortem injuries (i.e., after feather removal) is the potential for factors unrelated to catching and handling to affect the prevalence of the injuries recorded. Some injury may occur during transportation, e.g., following impacts during vehicle movement (Mitchell et al. 1992) and during unloading of crates at the processing plant (Jespersen 1982). However, most injury occurs during catching and handling. Jacobs et al. (2017) examined the percentage of broilers with wing fractures before loading, after loading, after transport, and after lairage, but they only found a significant increase in wing injuries after loading. Shacking, stunning, and slaughter procedures can cause wing flapping, sudden muscular contraction, haemorrhage, and bone fractures (Wilson and Brunson 1968; Gregory and Bell 1987; Gregory et al. 1989; Raj et al. 1990; Gregory 1994; Kranen et al. 2000). Kittelsen et al. (2015) found a significant increase in the prevalence of wing fractures between lairage and after shackling but not between shackling and post stunning. Bruising 
Table 4. Final model of variables and coefficients for risk factors affecting square root transformed percentage of wing injuries per load ( $\geq 2 \%)$.

\begin{tabular}{|c|c|c|c|c|}
\hline Variable & Coefficient & \multicolumn{2}{|c|}{ Confidence interval (95\%) } & $P$ \\
\hline \multicolumn{5}{|l|}{ Birds } \\
\hline Weight (kg) & 0.32 & 0.14 & 0.50 & $<0.001$ \\
\hline Sex & - & - & - & $<0.001$ \\
\hline Cockerels & Reference & - & - & - \\
\hline Mixed & 0.17 & 0.10 & 0.25 & - \\
\hline Pullets & 0.18 & 0.10 & 0.26 & - \\
\hline \multicolumn{5}{|l|}{ Loading } \\
\hline Catching team & - & - & - & $<0.001$ \\
\hline I & Reference & - & - & - \\
\hline A & 0.42 & 0.28 & 0.55 & - \\
\hline $\mathrm{B}$ & 0.36 & 0.21 & 0.52 & - \\
\hline $\mathrm{C}$ & 0.69 & 0.49 & 0.89 & - \\
\hline $\mathrm{D}$ & 0.22 & 0.06 & 0.38 & - \\
\hline $\mathrm{E}$ & 0.27 & 0.11 & 0.43 & - \\
\hline $\mathrm{F}$ & 0.36 & 0.20 & 0.52 & - \\
\hline G & 0.28 & -0.01 & 0.57 & - \\
\hline $\mathrm{H}$ & 0.36 & 0.15 & 0.57 & - \\
\hline $\mathrm{J}$ & 0.43 & 0.29 & 0.57 & - \\
\hline Season & - & - & - & $<0.001$ \\
\hline Fall & Reference & - & - & - \\
\hline Spring & 0.19 & 0.11 & 0.26 & - \\
\hline Summer & 0.19 & 0.11 & 0.26 & - \\
\hline Winter & 0.15 & 0.07 & 0.22 & - \\
\hline Time of day & - & - & - & $<0.001$ \\
\hline 0000-0700 (Morning) & Reference & - & - & - \\
\hline 0701-1700 (Daytime) & 0.02 & -0.05 & 0.09 & - \\
\hline 1701-2359 (Evening) & -0.16 & -0.22 & -0.09 & - \\
\hline Speed of loading (No. of birds $\mathrm{h}^{-1}$ ) & - & - & - & 0.001 \\
\hline$<5000$ & Reference & - & - & - \\
\hline$\geq 5000$ & 0.20 & 0.09 & 0.31 & - \\
\hline Time of day $\times$ speed of loading & - & - & 一 & $<0.001$ \\
\hline $0701-1700 \times<5000$ & Reference & - & - & - \\
\hline $0000-0700 \times \geq 5000$ & -0.35 & -0.48 & -0.22 & - \\
\hline $1701-2359 \times \geq 5000$ & -0.17 & -0.31 & -0.03 & - \\
\hline Missing data for both time of day and speed of loading & -0.12 & -0.21 & -0.04 & 0.005 \\
\hline Intercept & 0.69 & 0.25 & 1.12 & - \\
\hline \multicolumn{5}{|l|}{ Variance } \\
\hline Producer & 0.01 & 0.01 & 0.03 & - \\
\hline Event & 0.08 & 0.07 & 0.10 & - \\
\hline Load & 0.28 & 0.26 & 0.29 & - \\
\hline
\end{tabular}

can still occur if trauma is inflicted within 5-10 s of the start of exsanguination, but trauma inflicted $20 \mathrm{~s}$ after exsanguination or after scalding and defeathering does not cause bruising (Hamdy et al. 1961b). However, postmortem effusion of haemoglobin into the tissues can occur during processing of carcases (Kranen et al. 2000) and post slaughter, mechanical treatment of carcases can cause damage (Kettlewell and Turner 1985).

The reasons for old injuries that likely occurred in the rearing barn are not known and there has been little research on this topic. It was possible that the wing injuries occurred due to wing flapping in response to handling (Newberry and Blair 1993) or as a fear response to a sudden stimulus (Jones et al. 1998). It is also possible that some birds were inadvertently injured by incorrect foot placement when a stockperson walked through the flock to make routine inspections of the birds (Cransberg et al. 2000). However, some of the breast injuries might not have had a traumatic origin and might have developed from contact dermatitis lesions (Greene et al. 1985; Pass 1989).

The prevalence of injury reported in various studies is affected by the method of recording of the injuries (Knowles and Broom 1990), and therefore, it is difficult to make reliable comparisons between studies. Although the percentage of wing injuries was greater, and percentage of leg injuries slightly lower, the prevalence of 
Fig. 2. Mean predicted level (with $95 \%$ confidence interval bars) of percentage wing injuries per load with increasing bird weight. Other predictors were set as follows: catching team $=A$; time of day $=0701-1700 ;$ speed of loading $=<5000$ birds $\mathrm{h}^{-1}$; sex $=$ mixed; season $=$ spring.

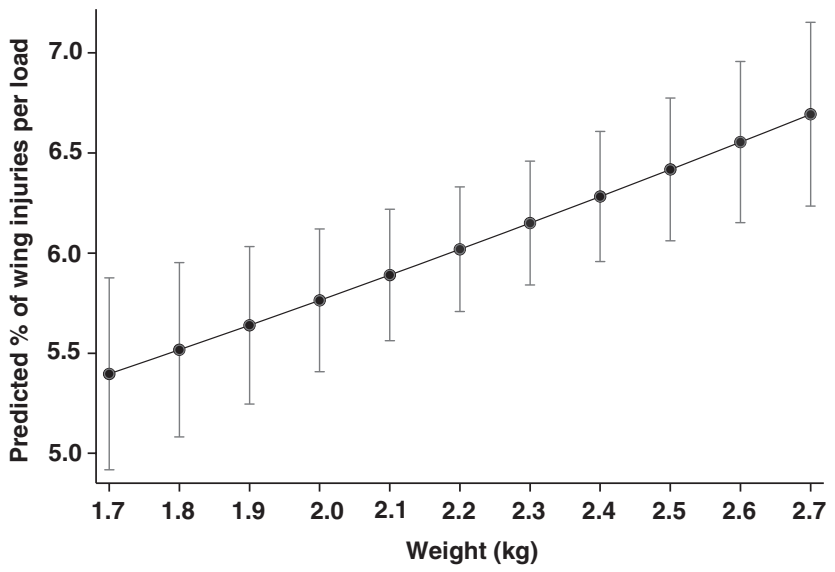

Fig. 3. Mean predicted level (with $95 \%$ confidence interval bars) of percentage wing injuries per load by sex of load. Other predictors were set as follows: weight $=2.6 \mathrm{~kg}$; catching team $=\mathrm{A}$; time of day $=0701-1700$; speed of loading $=<5000$ birds $\mathrm{h}^{-1}$; season $=$ spring.

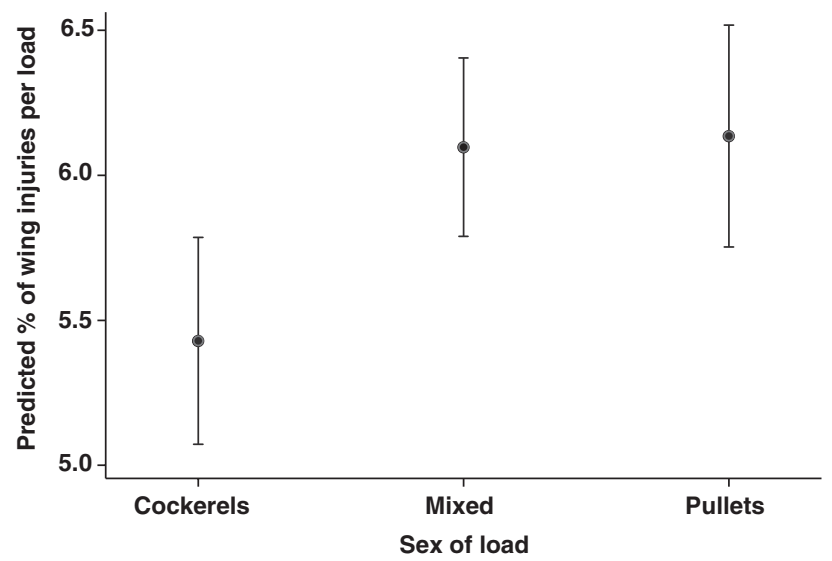

injuries were of a similar magnitude to those reported by Knierim and Gocke (2003) following manual catching and handling using crates. Other studies (Jespersen 1982; Griffiths and Nairn 1984) have reported greater prevalences of leg and breast injuries. The leg injuries were likely to have been a consequence of carrying the birds inverted (Wilson and Brunson 1968). It is possible that some of the breast bruising attributed to catching and handling occurred when the breast came into contact with the entrance to the crate during loading (Gouveia et al. 2009). In the study by Jespersen (1982) where 10 birds at a time were passed through the door of each crate, a greater percentage of birds with wing injuries was reported than in the current study, whereas in the study by Griffiths and Nairn (1984) where the birds were caught
Fig. 4. Mean predicted level (with $95 \%$ confidence interval bars) of percentage wing injuries per load by season. Other predictors were set as follows: weight $=2.6 \mathrm{~kg}$; catching team $=\mathrm{A}$; time of day $=0701-1700$; speed of loading $=<5000$ birds $\mathrm{h}^{-1}$; sex $=$ mixed.

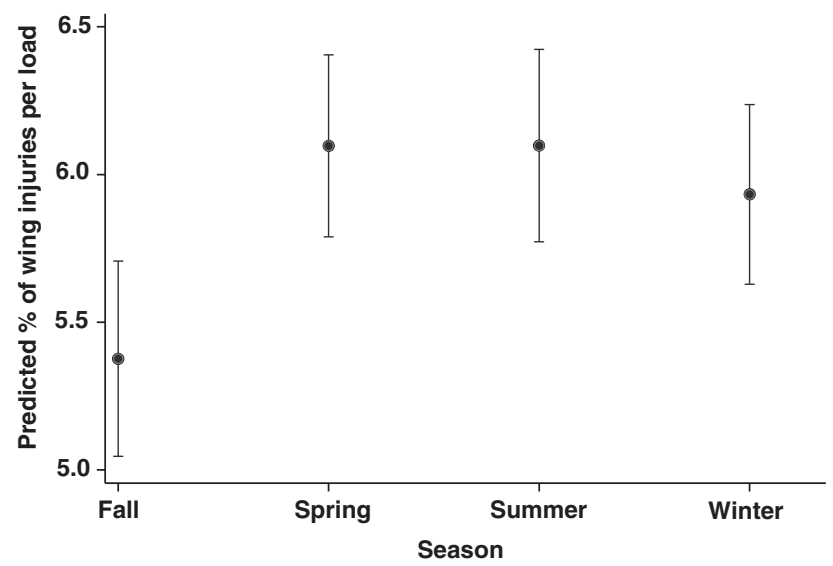

Fig. 5. Mean predicted level (with $95 \%$ confidence interval bars) of percentage wing injuries per load by catching team. Other predictors were set as follows: weight $=2.6 \mathrm{~kg}$;

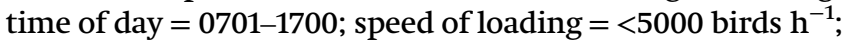
sex $=$ mixed; season $=$ spring.

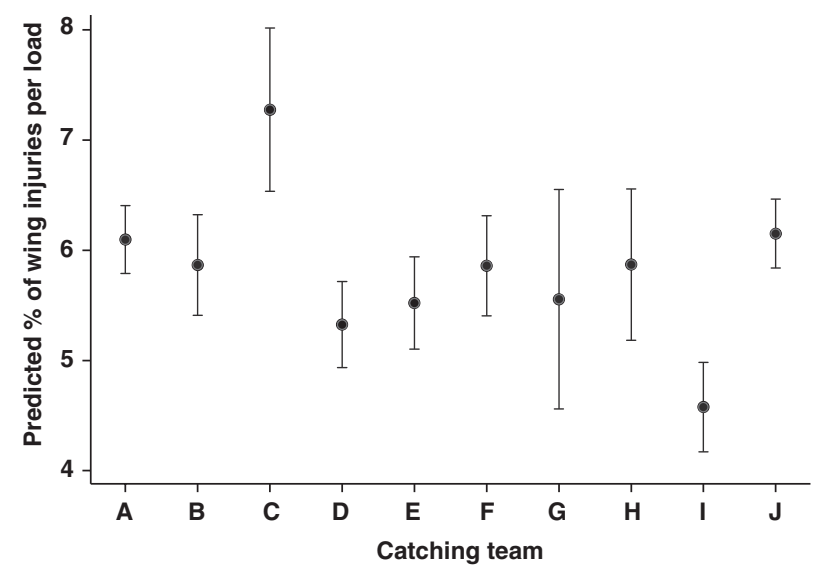

individually and then placed in a crate, the percentages of birds with wing injuries were lower than in the current study. This suggests that the manner of placement of the birds in the crate could affect the prevalence of wing injuries. The manner in which the birds are handled is likely to affect the frequency and severity of wing flapping, and this is likely to vary between catching teams. Wolff et al. (2019) observed increased wing flapping with increased time taken to catch, carry, and place the birds into a container and with carrying one bird inverted per hand compared with either carrying three birds per hand or holding the bird under the abdomen. As in the current study, Jacobs et al. (2017) found a tendency for the percentage of birds with bruised wings or breasts to differ between catching teams. 
Fig. 6. Mean predicted level (with $95 \%$ confidence interval bars) of percentage wing injuries at different loading speeds and time of day. Other predictors were set as follows: weight $=2.6 \mathrm{~kg}$; catching team $=\mathrm{A}$; $\mathrm{sex}=$ mixed; season $=$ spring. The group representing missing values is not shown.

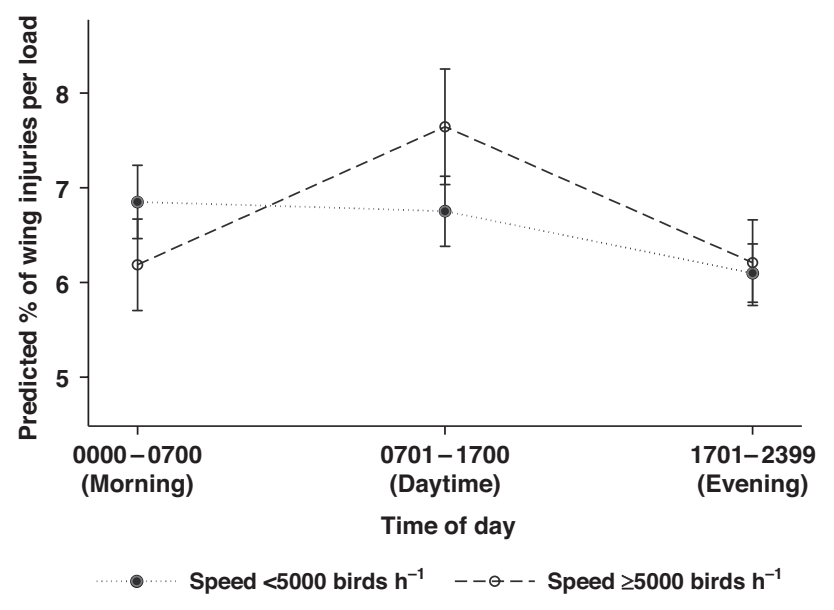

Mayes (1980) also found more bruising in pullets than in cockerels and increased bruising with increasing bird age and weight. Although Hamdy et al. (1961b) did not find an effect of age on the susceptibility of broilers to bruising following trauma, Langkabel et al. (2015) found an increased risk of wing bruising in heavier compared with lighter broilers. Wolff et al. (2019) found that the risk of wing flapping during manual handling increased with bird weight.

The effect of season on the risk of wing injury was similar to that reported by Nijdam et al. (2004) following manual handling using modules; they found a lower percentage of bruises in the fall and spring than in the summer. Mayes (1980) and Jacobs et al. (2017) found more bruising with increased ambient temperature and Nijdam et al. (2004) found that both low temperatures $\left(<5{ }^{\circ} \mathrm{C}\right)$ and high temperatures $\left(20-25^{\circ} \mathrm{C}\right)$ increased the risk of bruising compared with 10-15 ${ }^{\circ} \mathrm{C}$. Possibly because of peripheral vasoconstriction at lower temperatures, Hamdy et al. (1961b) found less bruising following trauma at ambient temperatures of -4 to $4{ }^{\circ} \mathrm{C}$ compared with those at $27-32{ }^{\circ} \mathrm{C}$.

Although one recent study found evidence that loading during the night compared with during the day increased the risk of bruising in the wings and breasts (Jacobs et al. 2017), this is in contrast to previous work that showed a slight reduction in bruising in birds loaded in the dark compared with those loaded during daylight hours (Taylor and Helbacka 1968). Nijdam et al. (2004) also found increased bruising in broilers that had been transported in the daytime compared with transporting them at night. Broilers are less active at low light intensity than in brighter light (Deep et al. 2012). When birds are inverted and placed in shackles, the frequency and duration of struggling increases with light intensity (Jones et al. 1998). At night, it is easier to reduce light intensity in the barn and this can make it easier to catch and handle the birds (Knowles and Broom 1990). de Lima et al. (2019) found less wing flapping and contact between the broilers and the crate during catching and handling, when it was possible to reduce the light intensity in the barn. The interaction between speed of loading and loading during daylight hours is consistent with the above findings. Jacobs et al. (2017) found a positive correlation between an increase in wing fracture prevalence and the duration of catching and loading of the whole flock. This suggests that the risk of injury is not simply due to loading the birds too fast but might also be related to other factors, e.g., handling problems that delay loading or fatigued catchers (Millman et al. 2017).

The results suggest that the manner in which broilers are caught, handled, and loaded can affect the prevalence of wing injuries. For a loose crate handling system, identifying the reasons for variation between catching teams in the prevalence of injury would be beneficial. The analysis identified that avoiding loading of heavy birds and not loading the birds too fast during the daytime would reduce the risk of wing injuries. The adoption of modular handling systems rather than the use of loose crates has the potential to improve on-farm handling by reducing the duration of carrying and providing easier access for placement of the birds into a container (Bayliss and Hinton 1990). Recording of relevant variables, quality control, and benchmarking to monitor and act upon the causes of variation in injury are good practices to identify reasons for injury.

\section{Acknowledgements}

This work was funded by the Canadian Poultry Research Council and The Sir James Dunn Animal Welfare Centre. The broiler processing plant is thanked for the provision of the records and their assistance. Statistical assistance from $\mathrm{J}$. Yu is acknowledged.

\section{References}

Bayliss, P.A., and Hinton, M.H. 1990. Transportation of broilers with special reference to mortality rates. Appl. Anim. Behav. Sci. 28: 93-118. doi:10.1016/0168-1591(90)90048-I.

Cockram, M.S., and Dulal, K.J. 2018. Injury and mortality in broilers during handling and transport to slaughter. Can. J. Anim. Sci. 98: 416-432. doi:10.1139/cjas-2017-0076.

Cransberg, P.H., Hemsworth, P.H., and Goleman, G.J. 2000. Human factors affecting the behaviour and productivity of commercial broiler chickens. Br. Poult. Sci. 41:272-279. doi:10.1080/713654939. PMID:11081420.

de Lima, V.A., Ceballos, M.C., Gregory, N.G., and Paranhos Da Costa, M.J.R. 2019. Effect of different catching practices during manual upright handling on broiler welfare and behavior. Poult. Sci. 98: 4282-4289. doi:10.3382/ps/pez284. PMID:31152676.

Deep, A., Schwean-Lardner, K., Crowe, T.G., Fancher, B.I., and Classen, H.L. 2012. Effect of light intensity on broiler 
behaviour and diurnal rhythms. Appl. Anim. Behav. Sci. 136: 50-56. doi:10.1016/j.applanim.2011.11.002.

Gentle, M.J. 1992. Pain in birds. Anim. Welfare, 1: 235-247.

Gerrits, A.R., and de Koning, K. 1982. Transport of broilers. Pages 29-37 in R. Moss, ed. Transport of animals intended for breeding production and slaughter. Martinus Nijhoff, The Hague, Netherlands.

Gouveia, K.G., Vaz-Pires, P., and Martins da Costa, P. 2009. Welfare assessment of broilers through examination of haematomas, foot-pad dermatitis, scratches and breast blisters at processing. Anim. Welfare, 18: 43-48.

Greene, J.A., McCracken, R.M., and Evans, R.T. 1985. A contact dermatitis of broilers-clinical and pathological findings. Avian Pathol. 14: 23-38. doi:10.1080/03079458508436205. PMID:18766896.

Gregory, N.G. 1994. Pathology and handling of poultry at the slaughterhouse. Worlds Poult. Sci. J. 50: 66-67. doi:10.1079/ WPS19940010.

Gregory, N.G., and Bell, J.C. 1987. Duration of wing flapping in chickens shackled before slaughter. Vet. Rec. 121: 567-569. PMID:3433647.

Gregory, N.G., Austin, S.D., and Wilkins, L.J. 1989. Relationship between wing flapping at shackling and red wingtips in chicken carcases. Vet. Rec. 124: 62. doi:10.1136/vr.124.3.62. PMID:2919496.

Griffiths, G.L., and Nairn, M.E. 1984. Carcase downgrading of broiler chickens. Br. Poult. Sci. 25: 441-446. doi:10.1080/ 00071668408454885.

Hamdy, M.K., May, K.N., Flanagan, W.P., and Powers, J.J. $1961 a$. Determination of the age of bruises in chicken broilers. Poult. Sci. 40: 787-789. doi:10.3382/ps.0400787.

Hamdy, M.K., May, K.N., and Powers, J.J. 1961b. Some physical and physiological factors affecting poultry bruises. Poult. Sci. 40: 790-795. doi:10.3382/ps.0400790.

Jacobs, L., Delezie, E., Duchateau, L., Goethals, K., and Tuyttens, F.A.M. 2017. Impact of the separate pre-slaughter stages on broiler chicken welfare. Poult. Sci. 96: 266-273. doi:10.3382/ ps/pew361. PMID:27702923.

Jespersen, M. 1982. Injuries during catching and transportation of broilers. Pages 39-44 in R. Moss, ed. Transport of animals intended for breeding production and slaughter. Martinus Nijhoff, The Hague, Netherlands.

Jones, R.B., Satterlee, D.G., and Cadd, G.G. 1998. Struggling responses of broiler chickens shackled in groups on a moving line: effects of light intensity, hoods, and 'curtains'. Appl. Anim. Behav. Sci. 58: 341-352. doi:10.1016/S0168-1591(98)00091-4.

Kettlewell, P.J., and Turner, M.J.B. 1985. A review of broiler chicken catching and transport systems. J. Agric. Eng. Res. 31: 93-114. doi:10.1016/0021-8634(85)90064-2.

Kittelsen, K.E., Granquist, E.G., Vasdal, G., Tolo, E., and Moe, R.O. 2015. Effects of catching and transportation versus preslaughter handling at the abattoir on the prevalence of wing fractures in broilers. Anim. Welfare, 24: 387-389. doi:10.7120/ 09627286.24.4.387.

Knierim, U., and Gocke, A. 2003. Effect of catching broilers by hand or machine on rates of injuries and dead-on-arrivals. Anim. Welfare, 12: 63-73.
Knowles, T.G., and Broom, D.M. 1990. The handling and transport of broilers and spent hens. Appl. Anim. Behav. Sci. 28: 75-91. doi:10.1016/0168-1591(90)90047-H.

Kranen, R.W., Lambooij, E., Veerkamp, C.H., Van Kuppevelt, T.H., and Veerkamp, J.H. 2000. Haemorrhages in muscles of broiler chickens. Worlds Poult. Sci. J. 56: 93-126. doi:10.1079/ WPS20000009.

Langkabel, N., Baumann, M.P.O., Feiler, A., Sanguankiat, A., and Fries, R. 2015. Influence of two catching methods on the occurrence of lesions in broilers. Poult. Sci. 94: 1735-1741. doi:10.3382/ps/pev164. PMID:26089477.

Mayes, F.J. 1980. The incidence of bruising in broiler flocks. Br. Poult. Sci. 21: 505-509. doi:10.1080/00071668008416703.

Millman, C., Christley, R., Rigby, D., Dennis, D., O'Brien, S.J., and Williams, N. 2017. "Catch 22": biosecurity awareness, interpretation and practice amongst poultry catchers. Prev. Vet. Med. 141: 22-32. doi:10.1016/j.prevetmed.2017.04.002. PMID:28532990.

Mitchell, J.R., and De Boom, H.P.A. 1986. Traumatic avulsion of the proximal femoral articular cartilage as a cause of hip dislocation in broiler chickens. J. S. Afr. Vet. Assoc. 57: 133-137. PMID:3806555.

Mitchell, M.A., Kettlewell, P.J., and Maxwell, M.H. 1992. Indicators of physiological stress in broiler chickens during road transportation. Anim. Welfare, 1: 91-103.

Newberry, R.C., and Blair, R. 1993. Behavioral responses of broiler chickens to handling: effects of dietary tryptophan and two lighting regimens. Poult. Sci. 72: 1237-1244. doi:10.3382/ps.0721237. PMID:8346149.

Nijdam, E., Arens, P., Lambooij, E., Decuypere, E., and Stegeman, J.A. 2004. Factors influencing bruises and mortality of broilers during catching, transport, and lairage. Poult. Sci. 83: 1610-1615. doi:10.1093/ps/83.9.1610. PMID:15384914.

Northcutt, J.R., Buhr, R.J., and Rowland, G.N. 2000. Relationship of broiler bruise age to appearance and tissue histological characteristics. J. Appl. Poult. Res. 9: 13-20. doi:10.1093/japr/ 9.1.13.

Pass, D.A. 1989. The pathology of the avian integument: a review. Avian Pathol. 18: 1-72. doi:10.1080/03079458908418580. PMID:18679837.

Raj, A.B.M., Gregory, N.G., and Austin, S.D. 1990. Prevalence of broken bones in broilers killed by different stunning methods. Vet. Rec. 127: 285-287. PMID:2122574.

Taylor, M.H., and Helbacka, N.V.L. 1968. Field studies of bruised poultry. Poult. Sci. 47: 1166-1169. doi:10.3382/ps.0471166.

Thorsen, S. 2017. Sunrise and sunset calculator. https:// www.timeanddate.com/sun/ [November 2017].

Wilson, J.G., and Brunson, C.C. 1968. The effects of handling and slaughter method on the incidence of hemorrhagic thighs in broilers. Poult. Sci. 47: 1315-1318. doi:10.3382/ ps.0471315.

Wolff, I., Klein, S., Rauch, E., Erhard, M., Mönch, J., Härtle, S., et al. 2019. Harvesting-induced stress in broilers: comparison of a manual and a mechanical harvesting method under field conditions. Appl. Anim. Behav. Sci. 221: 104877. doi:10.1016/ j.applanim.2019.104877. 